\title{
Self-regulated learning strategies and computer self-efficacy in IT courses
}

\author{
F. Paraskeva \\ Department of Technology Education \& Digital Systems, \\ University of Piraeus, Greece
}

\begin{abstract}
Today, the ability to learn is considered a critical factor for an individual's academic and career performance. Educational programs and courses can contribute to this by enabling individuals to develop specific skills and strategies so as to attain specific goals. Academic research has noted that the goal of tertiary education is to foster individuals to become capable, independent, self-regulated and efficient learners. Thus self-efficacy beliefs and self-regulatory practices can be powerful predictors of success in academic and social life. The purpose of this study on 188 students of an Information Technology Department was to determine the relationship of self-regulated strategies and computer self-efficacy in IT courses, as these strategies are considered critical for the individual's development. The effects of the variables such as the year of studies (at the beginning and at the end of studies) in correlation with self-regulated learning strategies and self-efficacy were examined. The results illustrate that there is a correlation between self-regulated strategies (cognitive and meta-cognitive strategies) and computer self-efficacy (beginning, advanced, file and software management skills). These findings are significant in that they may facilitate the construction of efficient academic courses that will enhance the student's strategies and skills.

Keywords: computer self-efficacy, learning strategies, year of studies, computer skills.
\end{abstract}

\section{Theoretical background}

Today's information reliant society requires one to be a flexible and independent individual that is able to manage the diffusion of an enormous volume of information. Researchers have noted that the goal of higher education is to foster 
individuals to become capable, independent, self-regulated and efficient learners [1-4]. The goals of higher education in many countries, including Greece, are moving into flexible learning, (that is, to develop and support individual learning). Learners have to become independent, confident, effective and responsible for their own learning $[5,6]$. In this direction, tertiary learning environments need to emphasize self-development via the internal characteristics of the learner, (i.e. self-efficacy, or learning strategies). Such as internal characteristics those that are self-regulated (cognitive/meta-cognitive strategies, critical thinking, resource management etc). Therefore, currently, the aim of university education is to encourage students to become independent learners covering many aspects of the teaching and learning processes. An efficient learning process is a critical factor in higher education in the sense that it may provide innovative technological approaches, such as learning tools in order to define strategies that would enable learners to manage their own learning [7, 8]. These strategies may include goal-setting and planning, seeking, organizing and transforming information, monitoring, rehearsing and memorizing, reviewing strategies etc. $[9,10]$. However, little research has been conducted in order to determine how a learner can develop self-regulated strategies, based on educational theories that encourage learners to acquire knowledge and develop relevant skills. Moreover, regarding the use of technology in learning environments, computer tools as well as materials in teaching IT courses content, are still not consistently incorporating the educational or psychological dimensions of learning [11]. Besides, many researchers report, that factors, (such as students' beliefs, confidence and integrating instructional technologies strategies), may lead to solid learning (self-regulation and computer selfefficacy) through computers (equally significant) [12, 13]. Effective use of IT courses requires ongoing user learning for students to keep up with the changing nature of IT and the new roles.

Most theories of self-regulation emphasize self-development, along with motivation, goals and achievements. Motivation helps people focus on the task, select and apply appropriate strategies, and monitor goal progress. Goals enhance self-regulation through their effects on motivation, learning strategies, self-efficacy, recourse management and self-evaluation of progress [15-17].

\section{Method}

A group of 188 students from an Information Technology Department participated in this study. The students were attending IT courses (programming, networks design, systems and simulation etc) offered by the Department. From this sample, 96 students were in the first year of studies and 92 in the fourth one. The students had selected IT courses because of the nature of the university studies (Information Technology Department) and of the type of learning in the IT courses such as lectures and hands-on activities. These courses aim at providing students with all the necessary knowledge and skills concerning the design, implementation, management and evaluation of electronic services. These types of courses were chosen on the grounds that they prescribe students' 
advanced skills such as regulation, control, and management skills of their behaviour. They were considered appropriate for the needs of the research because they are essential to the academic profile of the students and include different types of learning, consisting of concepts and problem solving via hands-on computer activities (IT).

The present study aimed at providing an opportunity for consideration and investigation of the relationship between CSE and SRL strategies used by students in order to meet the demands of Information Technology (IT) courses [14]. It was of primary importance to investigate the influence that academic teaching had on the use of learning strategies and computer self-efficacy through the courses. Additionally, the effect of variables such as the year of study was examined, through analysis of these variables in relation to students' prior experience either through an out-of-University experience or through specific academic training and learning. In the research examined the relationship between these students' characteristics (i.e. prior experience, year of studies) and SRL strategies and CSE beliefs. In short, the purpose of this research was to describe the relationship between SRL strategies with the students' CSE in hands-on computer activities of IT courses. In addition, this study investigates the effect of the level of studies (the year) and of prior experience in order to examine whether the level of studies is connected with the development of relevant strategies.

To achieve this purpose, key questions were investigated:

1. The correlation of SRL strategies with CSE in hands-on computer activities in the $1^{\text {st }}$ and $4^{\text {th }}$ years of the studies.

2. The relationship of sub-constructs such as: beginning skills, advanced skills, file and software, with motivation, learning strategies and resource management.

3. The correlation of CSE and RSL strategies in hands-on computer activities with prior experience.

The participants completed the questionnaires based on the IT courses. The Questionnaires were given to the first- and fourth-year students during the end of the academic year to obtain a description of these skills of the students. All the Questionnaires were translated from English into Greek and they were completed in the classroom.

The following instruments were employed in the following evaluations:

- Motivated Strategies for Learning Questionnaire [18]: this questionnaire has also been employed in other studies of researching the motives, cognitive and meta-cognitive strategies and it is widely known as MSLQ. It is divided into two sub-categories. The first one explores the motivation of students and it is made up of 31 items. We used the second part which examines learning strategies and is made up of 50 items. Each item is assessed in a 7-point scale from "not at all true of me" (1) to "very true of me" (7).

- Computer Self-Efficacy Survey [19]: It is divided into three subcategories. Each of them explores the beginning skills in Computer Use, the advanced skills in Computer Use and the management skills in the 
Use of files and other software. It is made up of 37 items. Each item is assessed in a 5-point scale from being "completely unconfident" (1) to "completely confident" (5).

- The demographic questionnaire in the research included information about the students' prior experience in IT courses.

The year of study is considered to be an important variable of the students' performances, since students are perceived to assume more responsibility for their own learning (independent learners) in later academic years. The student's year of study was an independent variable, used to examine to what extent the students have developed more strategies for their own learning (SR) just before graduation. If not, the point is to put forward some proposals that could improve the conditions, the strategies and the ways of learning of self-regulated strategies in correlation with self-confidence via the development of CSE strategies.

\section{Results}

Through the simple regression analysis method the relation between Self-Regulated Strategies (Learning Strategies: cognitive - metacognitive strategies and resource management) and Computer Self-Efficacy (on beginning skills, advanced skills and management skills in the use of files and other software) were examined.

As shown in Table 1, first, there is a correlation between Learning Strategies and Computer Self-Efficacy and secondly, the more Learning Strategies the students use the more increasing self-efficacy they perform.

Table 1: Correlation between computer self-efficacy, learning strategies and the year of studies.

\begin{tabular}{|c|c|c|c|c|c|}
\hline & \multicolumn{2}{|c|}{$\begin{array}{l}\text { Learning Strategies } \\
\text { Year of Studies }\end{array}$} & \multicolumn{2}{|c|}{$\begin{array}{c}\text { Computer Self Efficacy } \\
\text { Year of Studies }\end{array}$} & \multirow{2}{*}{$\begin{array}{c}\text { Learning } \\
\text { Strategies \& } \\
\text { Computer } \\
\text { Self Efficacy } \\
\text { TOTAL } \\
\end{array}$} \\
\hline & $1^{\text {st }}$ Year & $4^{\text {th }}$ Year & $1^{\text {st }}$ Year & $4^{\text {th }}$ Year & \\
\hline $\mathbf{N}$ & 96 & 92 & 96 & 92 & 188 \\
\hline Mean & 4,159 & 4,49524 & 4,2436 & 4,7029 & \\
\hline Median & 4,19115 & 4,50417 & & & \\
\hline $\begin{array}{l}\text { Stand. Dev. } \\
\text { (SD) }\end{array}$ & 0,395926 & 0,527169 & 0,3667 & 0,4086 & \\
\hline t-test & & $-4,9584$ & & 183 & \\
\hline \multicolumn{5}{|l|}{$\bar{R}$} & 0,2909 \\
\hline$\underline{P}$ & & 0,000 & & 000 & 0,000 \\
\hline
\end{tabular}

Partial correlations were calculated so as to better understand the role of the level of study on the use of learning strategies and computer self-efficacy. The fourth-year students, through their prior knowledge and experience, performed 
greater and incorporated more upgraded use of Learning Strategies (cognitive and metacognitive). They adhered to their goal, managed their study time better, organized their study space, and finally, performed a higher self-regulating level than first-year students. This is reasonable, as they become more mature through the years and acquire more solid academic knowledge and experience. These two variables (level of studies and learning strategies) were examined through the comparing method of two samples and specifically the t-test. The t-test reveals that the null hypothesis is not true and thus what is validated is the alternative hypothesis. The $p$-value $(p<0.05)$ shows the strong relationship between the year of study and the learning strategies. According to Table 2, the fourth-year students performed better in all Learning Strategies use. Searching into the regression analysis of Table 2 , it is concluded that the fourth-year students use cognitive and meta-cognitive strategies more frequently than the first-year students.

According to Table 2, there is an obvious difference between the first-year students and the fourth-year students. The difference was mainly pinpointed in the management of learning strategies. It seems that the students are engaged in reflective and efficacious actions by choosing complex learning strategies such as rehearsal, elaboration, organization and meta-cognitive strategies. Organization strategies and critical thinking, in particular, present no significant correlation with the level of studies.

Table 2: MSLQ sub-categories, means of the first- and forth-year students. Correlation between the learning strategies and the year of study.

\begin{tabular}{|c|c|c|c|c|c|}
\hline \multirow[b]{2}{*}{$\begin{array}{c}\text { YEAR } \\
\text { STUDYING }\end{array}$} & \multicolumn{5}{|c|}{ LEARNING STRATEGIES } \\
\hline & $\begin{array}{l}\text { Rehearsal } \\
\text { (C) }\end{array}$ & $\begin{array}{c}\text { Elaboration } \\
\text { (C) }\end{array}$ & $\begin{array}{l}\text { Organizatio } \\
\text { n (C) }\end{array}$ & $\begin{array}{c}\text { Critical } \\
\text { Thinking } \\
\text { (C) }\end{array}$ & $\begin{array}{c}\text { Metacognitive } \\
\text { strategies \& } \\
\text { Self Regulation } \\
\text { (M) } \\
\text { Planning- } \\
\text { Monitoring } \\
\text {-Regulating }\end{array}$ \\
\hline & $\begin{array}{l}1^{\text {st }} \& 4^{\text {th }} \\
\text { Year } \\
\text { Students }\end{array}$ & $\begin{array}{c}1^{\text {st }} \& 4^{\text {th }} \\
\text { Year } \\
\text { Students }\end{array}$ & $\begin{array}{l}1^{\text {st }} \& 4^{\text {th }} \\
\text { Year } \\
\text { students }\end{array}$ & $\begin{array}{l}1^{\text {st }} \& 4^{\text {th }} \\
\text { Year } \\
\text { Students }\end{array}$ & $\begin{array}{c}1^{\text {st }} \& 4^{\text {th }} \\
\text { Year } \\
\text { Students }\end{array}$ \\
\hline $\mathbf{N}$ & $96 / 92$ & $96 / 92$ & $96 / 92$ & $96 / 92$ & $96 / 92$ \\
\hline Mean & $\begin{array}{l}4,0208 \\
4,5951\end{array}$ & $\begin{array}{l}4,3350 \\
4,8279 \\
\end{array}$ & $\begin{array}{l}, 3099 \\
5,1548 \\
\end{array}$ & $\begin{array}{l}3,7062 \\
3,8565\end{array}$ & $\begin{array}{l}4,2994 \\
4,5733 \\
\end{array}$ \\
\hline $\begin{array}{l}\text { Stand.Dev. } \\
\text { (SD) }\end{array}$ & $\begin{array}{l}0,8703 \\
1,0142 \\
\end{array}$ & $\begin{array}{l}0,6243 \\
0,8496 \\
\end{array}$ & $\begin{array}{l}0,8971 \\
0,8924 \\
\end{array}$ & $\begin{array}{l}0,7856 \\
0,8261 \\
\end{array}$ & $\begin{array}{l}0,4492 \\
0,6814 \\
\end{array}$ \\
\hline $\mathbf{R}$ & & 0,4 & & & \\
\hline t-test & $-4,172$ & $-4,5454$ & $-6,4720$ & $-1,2783$ & $-3,2664$ \\
\hline$\underline{\mathbf{P}}$ & 0,000 & 0,000 & 8,3437 & 0,2027 & 0,000 \\
\hline
\end{tabular}


Finally, the examination of the effect of the level of studies on computer self-efficacy identified the dependence of CSE on the level of studies (Table 3), a fact which is indicated by the $p=$ value $(p<0.05)$. The t-test confirms that the alternative hypothesis prevails over the null hypothesis. Partial correlations were examined in terms of a variety of computer use skills and the students' academic year. Particularly, it is apparent that there is a positive relationship between computer (beginning skills) self-efficacy and the year of study, between computer (advanced skills) self-efficacy and the level of study and, finally, between computer (Files and other software management skills) self-efficacy and the year of study. The p-value validates the findings (Table 3). The same applies to the correlation coefficient while its results, in terms of beginning, advanced or other files management skills, are viewed as high in the sciences of human behavior. Besides, this is confirmed by the correlation that was found between computers self-efficacy and the level of studies.

Table 3: Partial correlations between the computer self-efficacy and the year of study.

\begin{tabular}{|c|c|c|c|}
\hline \multirow{2}{*}{$\begin{array}{c}\text { YEAR } \\
\text { STUDYING }\end{array}$} & \multicolumn{3}{|c|}{ Computer self-efficacy } \\
\hline & Beginning skills & advanced skills & $\begin{array}{c}\text { Files \& software management } \\
\text { skills }\end{array}$ \\
\hline & $\begin{array}{l}1^{\text {st }} \& 4^{\text {th }} \\
\text { Year } \\
\text { students }\end{array}$ & $\begin{array}{l}1^{\text {st }} \& 4^{\text {th }} \\
\text { Year } \\
\text { students }\end{array}$ & $\begin{array}{c}1^{\text {st }} \& 4^{\text {th }} \\
\text { Year } \\
\text { Students }\end{array}$ \\
\hline $\mathbf{N}$ & $96 / 92$ & $96 / 92$ & $96 / 92$ \\
\hline Mean & $\begin{array}{l}3,93 \\
4,60 \\
\end{array}$ & $\begin{array}{l}3,45 \\
4,19 \\
\end{array}$ & $\begin{array}{l}3,84 \\
4,44 \\
\end{array}$ \\
\hline $\mathbf{R}$ & 0,5642 & 0,6141 & 0,4520 \\
\hline $\mathbf{P}$ & 0,000 & 0,000 & 0,000 \\
\hline
\end{tabular}

\section{Conclusions and implications}

The present study focused on the investigation of the relationships between computer self-efficacy and learning strategies, as well as the relationships between the level of studies and prior experience. As a result, the students' computer self-efficacy and the identification of those strategies that are mainly used by the students during the courses were explored. As can be derived from all the tables (especially the correlation coefficient), there is a significant relationship between computer self-efficacy and learning strategies. Thus, one's computer self-confidence will be increased, computer anxiety will be reduced and computer self-efficacy will be enhanced if computer self-beliefs improve using relevant skills and strategies. This could be done if, for example, the course was graded from easy to more difficult steps in order to make students feel confident with the new material. This might indicate that computer integration should not take place abruptly, but through a transitional phase which should be included in an academic curriculum so that less computer literate 
students could respond easily. Moreover, it was observed that as students go on with their studies they increase the use of their learning strategies. The fourth-year students demonstrated a higher level of self-efficacy than the first-year students. The cognitive and meta-cognitive strategies appear to be advanced in the fourth-year students too. Consequently, fourth-year students seem to regulate their learning by themselves, this means that they are able to extend their goals in the direction they desire. The courses seem to play an important role on their strategy use and their self-efficacy. As the students become familiarized with the learning objects, they perform better. The pedagogical value of identifying the exact learning strategies the students use lies in the exploitation of these findings in the teaching courses in order to enhance the students' performance. This could be a good reason to support a more self-directed learning, such as e-learning programs, in advanced levels rather than in lower levels. It seems that we need more creative methods in the Information Technology instructional programs and courses in order to accelerate the use of higher cognitive and meta-cognitive strategies. The nature of computer courses makes it necessary to use a method which activates and exhorts the students to use the strategies they possess. One such method could be the collaborative problem-solving activity. The purpose of doing this is enabling the student's transformation from a novice to an expert manager of their own knowledge.

The findings could be utilized in the design and evaluation of computer courses. The instructors of Information Technology courses could include a number of activities in order to increase the students' experiences through computer engagement. One such activity could be the students' involvement in their own evaluation through an authentic environment. Making the students responsible for evaluation issues and exposing them to an authentic environment could enable them not only to gain an important level of experience and learning but increase their activation too. One important issue here is the tiny difference of critical thinking strategies which was observed between the academic years. Critical thinking relies upon criteria, and it is self-correcting and sensitive to context. Teachers must validate the independence of their learners by enabling them to freely pursue authentic learning objectives. Transforming a course into a series of problem-solving activities seems to contribute in this direction but it yet remains to be widely investigated. Finding this combination, teachers could strengthen the learning context which supports this and get a lot of benefit from the course.

Finally, it would be interesting if we could examine the development - not only the presence - of self-regulating strategies in a designed environment which emphasizes scaffolding of the learning process, or compares a series of courses according to the students' capacity of providing self-regulating skills and not including all of them. For example, goal-setting is an integral component of self-regulation. Setting goals is a generic strategy that can be applied in various domains. Effective goal-setting requires that people set a long-term goal, break it into short-term attainable sub-goals, monitor progress and assess capabilities, adjust the strategy and goal as needed and set a new goal when the present one is 
attained. This multi-step plan is a key to turning to flexible learning in order to develop and support individual learning such as higher motivation and perceived self-efficacy, self-regulated learning and performance across the life span.

Teachers should strengthen students' self-efficacy beliefs and self-regulatory strategies focusing on professional practice in order to enhance motivation and academic achievement. By supporting and encouraging their students to set their own goals and internal standards, despite the dispensing of knowledge and information, by reflecting self-regulatory skills via challenging learning tasks and meaningful activities, they could affect their students' learning and orientation towards the educational process. The teachers' role and responsibility in nurturing their students' self-beliefs and competence is great. Teachers who provide students with challenging tasks and meaningful activities that can be mastered, and who chaperone these efforts with support and encouragement, help ensure that their students will develop the strong sense of self-efficacy required to rely on their own initiative and engage the world on their own. Also, educational programs that seek to empower students must not only cultivate the knowledge to succeed, but endeavour to maximize the potential for success by growing self-efficacy beliefs and self-regulatory strategies required to help bring the anticipated success $[20,21]$.

The discussion and strategies presented in this study can be applied to all students - regardless of their level of study. However, students who must overcome the internal and external barriers to self-efficacy because of cultural obstacles, linguistic barriers, or technological illiteracy (enormous volume of information), are especially in need of positive learning experiences that guide them in overcoming real or perceived barriers to career development. These learning experiences must integrate school-based learning with real-life conditions, because these are the conditions that predispose students' career success. In order to assist students to be effective in their learning, teachers should help students to become aware of alternative ways of different learning situations, suggesting various learning strategies appropriate for different learning situations.

\section{References}

[1] Pintrich, P.R. \& De Groot, E. (1990). Motivational and self-regulated learning components of classroom academic performance, Journal of Educational Psychology, vol. 82(1), pp 33-40.

[2] Zeegers, P., Martin, L. \& Martin, C. (1999). Using learning to learn strategies to enhance student self-regulated learning in first-year chemistry. At http://adminwww.flinders.edu.au/CAS/PacRim99.html

[3] Briguglio, C. (2000). Self-directed learning is fine-if you know the destination. At http://cleo.murdoch.edu.au/confs/tlf/tlf2000/briguglio.html

[4] McNaught. C. (2000) Technology: The challenge of change. In R. King, D. Hill \& B. Hemmings (Eds.) University and diversity: Changing perspectives, policies and practices in Australia. New South Wales: KEON Publications. 
[5] Codde, J.R. (1996). Using learning contracts in the college classroom. At http://www.msu.edu/user/coddejos/contract.htm

[6] Hoban, G., Seraland, C. \& Raine, B. (2001). Can adult learners raise their self-efficacy for self-directed learning? A reflective challenge to some of our assumptions. In H. B. Long (Eds.) Self-directed learning and the information age, Motorola University Press.

[7] Povatong, S. (1999). National education act of B. E. 2542 (1999). Bangkok: Office of the National Education Commission.

[8] Tiranasar, A. (1999). The synthesis of Thai higher education development plan. At http://www.media.academic.chula.ac.th/ampai/resource/ampail. htm

[9] Zimmerman, B.J. (2000). Attaining self-regulation: a social-cognitive perspective, in Boekarts, M., Pintrich, P.R. and Zeidner, M. (eds), Handbook of Self-Regulation, San Diego, Academic Press.

[10] Chen, C. (2002). Self-regulated Learning Strategies and Achievement in an Introduction to Information Systems Course, Information Technology, Learning and Performance Journal, vol. 20, No. 1, pp. 11-23.

[11] Makri-Botsari, M.; Paraskeva, F.; Koumbias, E.; Dendaki, A.; Panaikas, P. (2004): Skills in computer use, self-efficacy and self-concept In $1^{\text {st }}$ International Conference of Psychology and IT 2004: Human Perspectives in the Internet Society: Gender, Psychology \& Culture, Sept. 6-10, Spain.

[12] Pajares, F. (1997). Current directions in self-efficacy research. In M. Maehr \& P. Pintrich (Eds.) Advances in Motivation and Achievement, CT: JAI Press vol. 10, pp. 1-49.

[13] Zimmerman, B. J., Bandura, A., \& Martinez-Pons, M. (1992). Selfmotivation for academic attainment: The role of self-efficacy beliefs and personal goal setting, American Educational Research Journal, 29, 663676.

[14] Karsten, R., \& Roth, R.M. (1998). The relationship of computer experience and computer self-efficacy to performance in introductory computer literacy courses, Journal of Research on Computing in Education, 31 (3), 14-24.

[15] Bandura, A. (1997). Self - efficacy: The exercise of control, W.H. Freeman and Co, New York.

[16] Schunk, D.H. (1996). Goal and self-evaluative influences during children's cognitive skill learning, American Educational Research Journal, 33, 359-382.

[17] Smith, K.H. (2002). Using the social cognitive model to explain vocational interest in information technology, Information Technology, Learning and Performance Journal, vol. 20, No. 1. At http://www.osra.org/itlpj/smith.pdf

[18] Pintrich, P. R., Smith, D.A.F., Garcia, T. and McKeachie, W.J. (1993) Reliability and Predictive validity of the motivated strategies for learning questionnaire (MSLQ), Educational and Psychological Measurement, vol. 53 , pp. $801-803$. 
244 Data Mining VIII: Data, Text and Web Mining and their Business Applications

[19] Murphy, C.A., Coover, D. \& Owen, S.V. (1989). Development and validation of the Computer Self-Efficacy Scale, Educational and Psychological Measurement, 49, 893-899.

[20] Tuckman, B.W. \& Sexton, T.L. (1991). The effect of teacher encouragement on student self-efficacy and motivation for self-regulated performance, Journal of Social Behavior and Personality, 6, 137-146.

[21] Wolters, C. (1998). Self-regulated learning and college students' regulation of motivation, Journal of Educational Psychology, vol. 90(2), pp.224-235. 